\title{
Measuring and Evaluating the Levels of Coagulation Factors and Platelet in the Serum of the Patients with Moderate and Severe Brain Injury
}

\author{
Behzad Saberi* \\ Medical research, Iran \\ *Corresponding author: Behzad Saberi, Medical research, Iran \\ To Cite This Article: Behzad Saberi. Measuring and Evaluating the Levels of Coagulation Factors and Platelet in the Serum of the Patients with \\ Moderate and Severe Brain Injury. Am J Biomed Sci \& Res. 2019 - 4(1). AJBSR.MS.ID.000752. DOI: 10.34297/AJBSR.2019.04.000752
}

Received: June 21, 2019 | Published: July 16, 2019

\section{Mini Review}

Brain injury is a common accident and many factors involve in it's occurance. Due to daily increasing in vehicles numbers and some other dangerous factors, Brain injury incidence is increasing day by day. In case it would not be treated on time, it will cause high levels of mortality and disability. Current usual scale to detect the severity of head injury is GCS which although it is beneficial but has many limitations and in most of the time cannot be measured and used appropriately during clinical practice. So it would be necessary to try to find biomarkers that can determine the severity of brain damage in this patients group. This study has been done to determine and compare the levels of coagulation factors and platelet in the patients with moderate and severe brain injury [1-6].

This study is a descriptive analytical one which during that There were 200 patients whom data were collected and included in the study. Demographic information of the patients including their age, sex and etiology of the injury were collected and registered in a specific questionnaire. After examining the patients, their GCS levels were registered and the patients with moderate and severe brain injuries have been included in the study [7-12]. After getting their blood samples, the levels of PT, PTT, INR and Plt were measured and registered. Then the data were collected and evaluated with SPSS software.

There were some criteria to determine the inclusion or exclusion of the patients in this study. Inclusion criteria were:

a. The patients with moderate and severe brain injury and

\begin{tabular}{|c|}
\hline Table 1 \\
\hline Questionnaire sample \\
\hline Patients data including age and sex \\
Etiology of the injury \\
\hline GCS level \\
\hline Severity of the head injury based on GCS: moderate - severe \\
\hline Lab findings and results of measuring the levels of: PT, PTT, INR, Plt \\
\hline
\end{tabular}

b. Patients or their family consent to be involved in the study. Exclusion criteria was the impossibility to measure the coagulation factors levels in the patients due to various reasons (Table 1).

The level of PT in the patients with acute and moderate brain injury were $12+-1.15$ and $11.63+-0.89$ and according to the t-test there was no difference between two groups $(\mathrm{p}=0.3)$.The level of PTT in the patients with acute and moderate brain injury were $32.3+-2$ and $31.37+-1.75$ and according to the t-test there was no difference between two groups $(p=0.17)$.The level of INR in the patients with acute and moderate brain injury were $1.73+-0.61$ and $1.21+-0.3$ and according to the t-test there was a difference between two groups $(\mathrm{p}=0.001)$.The mean level of Plt in the patients with acute and moderate brain injury were $309.2+-36.16$ and $283.23+-$ $42.13(* 1000)$ and according to the t-test there was no difference between two groups $(p=0.9)$ [13-22].

The results of this study show that the levels of the coagulation factors in the patients with brain injury would be changed and these can be used in clinical practice to determine the patient's conditions and take appropriate decision.

\section{References}

1. Lehr D, Baethmann A, Reulen HJ, Steiger HJ, Lackner C, et al. (2007) Management of patients with severe head injury in the preclinical phase: a prospective analysis. J Trauma 42 (5 Suppl): S71-75.

2. Fleminger S, Ponsford J (2005) Long term outcome after traumatic brain injury. BMJ 331(7530): 1419-1420.

3. Delaney KA, Goldfrank LR (2000) Management of the multiply injured or intoxicated. In: Cooper PR, Golfinos JG, (Eds.), Head injury, $4^{\text {th }}$ edn, McGraw-Hill, New York, USA, p. 41-62.

4. Valadka AB, Narayan RK (2006) Emergency room management of the head-injured patient. In: Narayan RK, Wilberger JE, Povlishock JT (Eds.), Neurotrauma, McGraw-Hill, New York, USA, p. 119-135.

5. American Association of Neurological Surgeons, The Brain Trauma Foundation, The American association of Neurological Surgeons (2000) 
The Joint Section on Neurotrauma and Critical Care. Glasgow Coma Scale score. J Neurotrauma 17(6-7): 563-571.

6. Daivid IG, Hume AJ, Thomas AG (2006) Pathology of brain damage in head. In: Geroge TT, The practice of neurosurgery: From Williams \& Wilkins, Baltimor, USA, 2: 1385-1397.

7. Greenberg G (2003) Handbook of head and spine trauma. Williams \& Wilkins, Baltimor, USA, pp. 230-233.

8. Kelly FD, Nikas FD, Becker FD (2005) Diagnosis and treatment of moderate and severe head injuries in adult. In: Youmans RJ, Neurological surgery, From WB Sounders Company, Philadelphia, USA, (14 ${ }^{\text {th }}$ edn.), 3 : 1702-1918.

9. Lee RK, Hoff TG (2006) Intracranial pressure. In: Youmans RJ, Neurological surgery, From WB Sounders Company, Philadelphia, USA, $14^{\text {th }}$ edn, 1: 512 .

10. Levin HS (2008) Neurobehavioral sequelae of closed head injury. In: Cooper PR, Head injury: From Williams \& Wilkins, Baltimor, USA, p. 525551.

11. Jennett B, Bond M (1975) Assessment of outcome after severe brain damage. Lancet 1(7905): 480-484.

12. Maas AI, Braakman R, Schouten HJ, Minderhoud JM, van Zomeren AH (2003) Agreement between physicians on assessment of outcome following severe head injury. J Neurosurg 58(3): 321-325.

13. Salehpour F, Bazzazi AM, Porhomayon J, Nader ND (2011) Correlation between coagulopathy and outcome in severe head trauma in neurointensive care and trauma units. J Crit Care 26(4):352-356.

14. Aysegul B, Erdal K (2006) Fibrinolytic markers and neurologic autcome in traumatic brain injury. Neurology india 54(4): 356-365.
15. Cuffman PJ, Sleeman DH, Statham PF, McQuatt A, Corruble V, et al. (2002) Predicting recovery in patients suffering from traumatic brain injury by using admission variables and physiological data: a omparison between decision tree analysis and logistic regression. J Neurosurg 97(2): 326336.

16. Kurni M, Chelly H, Ben Hmida M, Ben Hamida C, Ksibi H, et al. (2004) Prognosis of traumatic head injury in South Tunisia: a multivariate analysis of 437 cases. J Trauma 57(2): 255-261.

17. Stein DW (2003) Treatment of cerebral is chemia improves outcome following server traumatic brain injury. In: Lea F. ICU book, From Williams \& Wilkins, Philadelphia, USA, pp. 197.

18. Bruns J, Hauser WA (2003) The epidemiology of traumatic brain injury: A review. Epilepsia 44 (Suppl 10): 2-10.

19. Murray GD, Teasdale GM, Braakman R, Cohadon F, Dearden M, et al. (1999) The European Brain Injury Consortium Survey of Head Injuries. Acta Neurochir (Wien) 141(3): 223-236.

20. Capruso DX, Levin HS (2000) Neurobehavioral sequelae of head injury. In: Cooper PR, Golfinos JG, editors. Head injury. $4^{\text {th }}$ edn, McGraw-Hill, New York, USA, p. 525-553.

21. Lee KK, Seow WT, Ng I (2006) Demographical profiles of adult severe traumatic brain injury patients: implications for healthcare planning. Singapore Med J 47(1): 31-36.

22. De Silva MJ, Roberts I, Perel P, Edwards P, Kenward MG, et al. (2009) Patient outcome after traumatic brain injury in high-, middle- and lowincome countries: analysis of data on 8927 patients in 46 countries. Int J Epidemiol 38(2): 452-458. 